\title{
The Reinforcement of Zakat Management through Financial Technology Systems
}

\author{
M. Aulia Rachman and Annisa Nur Salam \\ Diponegoro University
}

\begin{abstract}
Financial technology or fintech, as the information media used to execute technology-based financial services, has become a great foundation in the effort toward enhancing the effectiveness and efficiency of financial services. The integrated zakat management system has been developed and needs innovations to be developed; several amil zakat institutions have utilized fintech as a more optimal services device in zakat management. This means that the fintech-based management of zakat will continue to grow and grow well, on both the market and consumer sides (especially for the aspect of demand), so it needs regulation, standardization and effort to guarantee the management of zakat using fintech media. This paper will offer concepts for the innovation, reinforcement, strategy, and legality regarding a technology-based management system for zakat, funded by the government or a relevant authority.
\end{abstract}

Keywords: Financial Technology, Reinforcement, Management of Zakat

\section{INTRODUCTION}

Digital-technology development is increasing in some countries. The digital era in Indonesia is marked by the increasing usage of the Internet by society. According to Global Digital Report Data (2018), the number of Internet consumers in Indonesia has reached 132 million people or, in other words, more than $50 \%$ of Indonesian society are able to access the Internet. Therefore, currently, modern society activity tends to use technology more intensively to fulfil its requirements. Everyday activities, which have become the habit of society today when using technology, include, among others, buying food to eat, ordering transportation, shipping goods, ordering tickets, and doing business. Due to the presence of technology, human beings perceive their activities have become more assisted and efficient.
This phenomenon of the effect of an innovation on a system is known as a disruptive innovation. Disruptive innovation is an innovation that is successful in transforming an existing system or market by introducing practicability, easy access, comfort, and an economical cost (Hadad, 2017). The condition also occurs in the financial services industry, for which it has disrupted the landscape of the financial services industry globally. Beginning from the its industry structure, its intermediation technology to the its marketing model to the consumer. This has changed things entirely and encouraged the appearance of a new phenomenon called financial technology (fintech) (Hadad, 2017).

Fintech represents services in the field of finance that utilize the role of technology. Currently, the development of fintech in Indonesia is predominant in the sector of business payments, which accounts 
for $42.22 \%$ of fintech, and the loan sector or lending it is equal to $17.78 \%$. The rest consists of the aggregator sector at $12.59 \%$, crowdfunding at $8.15 \%$, financial planning at $8.15 \%$, and others at $11.11 \%$.

Furthermore, the number of fintech companies in Indonesia continues to increase every year. Before 2006, in Indonesia there were only four fintech companies, by 2014 there were forty companies, and a significant improvement was experienced in 2016, when it became 165 companies.

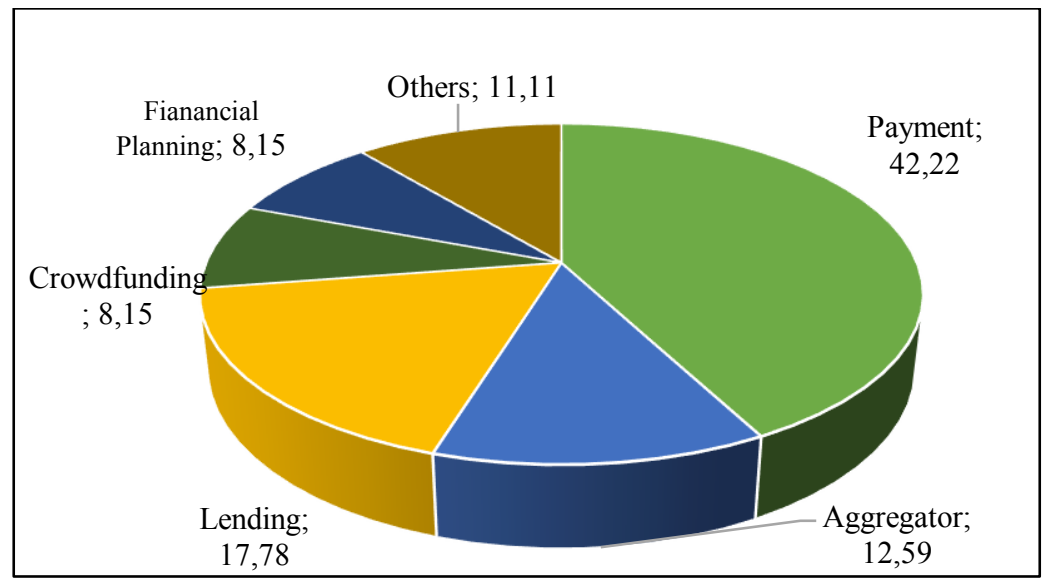

Figure 1. Profile of Fintech in Indonesia based on Sector (by Percentage) Source: Hadad (2017)

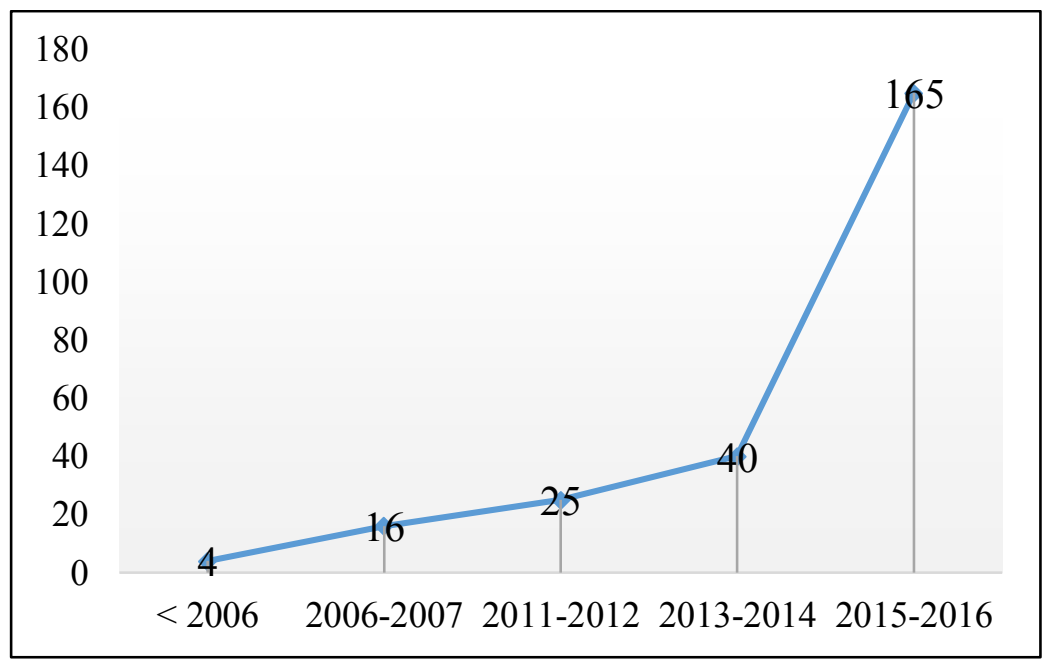

Figure 2. Profile of Fintech in Indonesia based on the Quantity of Companies (in Units) Source: Hadad (2017)

As a newly developed innovation, it needs an authority to regulate existence of fintech. Jutla and Sundararajan (2016) explain some reasons why fintech needs to be regulated, which are due to the existence of asymmetric information, externality, and the increasingly blurred boundaries between professional and personal who involved. In addition, according to the chief commissioner of the board of the Financial Services Authority Indonesia (Otoritas Jasa Keuangan [OJK]) some ascertained risks arising from fintech are as follows: firstly, there is the risk of the failure of applications related to the technological integrity exercised, and the resistance to virus attacks, 
hackers, and so on; secondly, there is operational risk from the potential for fraud and risk of the failure to pay; and, thirdly, there are risks to the security of big data managed by fintech companies (Imansyah, 2016).

The development of fintech as a business trend encourages various sectors to participate in its application. Zakat, infaq, and shodaqoh (ZIS) are as the instruments of social finance, which have great potential for collection to be improved continuously. Therefore, to respond to the digital society today, it is perceived that the institution of zakat needs to utilize fintech to easily collect zakat payments for the muzakki.

Table 1. Total Value of ZIS Collected in Indonesia

\begin{tabular}{ccc}
\hline Year & $\begin{array}{c}\text { In Rupiah } \\
\text { (Billion) }\end{array}$ & $\begin{array}{c}\text { In USD } \\
\text { (Million) }\end{array}$ \\
\hline 2002 & 68.39 & 4.98 \\
2003 & 85.28 & 6.21 \\
2004 & 150.09 & 10.92 \\
2005 & 295.52 & 21.51 \\
2006 & 373.17 & 27.16 \\
2007 & 740.00 & 53.86 \\
2008 & 920.00 & 66.96 \\
2009 & $1,200.00$ & 87.34 \\
2010 & $1,500.00$ & 109.17 \\
2011 & $1,729.00$ & 125,84 \\
2012 & $2,200.00$ & 160.12 \\
2013 & $2,700.00$ & 196.51 \\
2014 & $3,300.00$ & 240.17 \\
2015 & $3,700.00$ & 269.29 \\
\hline
\end{tabular}

Source: Outlook Zakat Indonesia, Badan

Amil Zakat Nasional (BAZNAS) (2017)

The accumulated ZIS fund has continuously improved and has huge potential, so one way that can be used in an effort to maximize its potential is through utilizing fintech for its payment aspect. There are several studies that estimate the potential for ZIS in Indonesia:

- PBB UIN Syarif Hidayatullah's (2005, cited in Wibisono, 2016) study estimates the potential of Islamic philanthropy in Indonesia as IDR 19.3 trillion in $2004(0.8 \%$ of GDB for 2004).

- $\quad$ BAZNAS - IRTI IDB / Firdaus et al.'s (2012, cited in Wibisono, 2016) study found the potential of zakat in Indonesia has reached IDR 217 trillion (3.4\% of GDB in 2010).

- Wibisono's (2015, cited in Wibisono, 2016) study finds that the potential of zakat Indonesia in 2010 had reached IDR 106.6 trillion $(1.7 \%$ of GDB in 2010).

The use of technology in ZIS fund management is also reinforced with BAZNAS's Strategic Plan (Rencana Strategis/Renstra). BAZNAS (2016) states that technology information is one of the main topics for national zakat management. It argues that the development of a national zakat system must utilize the development of technology information as an acceleration device to improve the effectiveness and efficiency of zakat management services in the, and to improve the benefits of zakat that will realize community welfare and alleviate poverty (BAZNAS, 2016).

Utilizing technology for the management of ZIS represents an innovation that has the potential to improve collection and distribution. The concept of digital philanthropy has evolved significantly in recent years due to the growth of the Internet (Abdelkader, 2017). But, until now, there has been no standard regulation or governance of ZIS management (especially for the management of zakat) through fintech media. However, today, many crowdfunding sites, marketplaces, and interface applications used as social-fundgathering media have emerged. While using fintech itself has various risks, as previously mentioned. In this case, an appropriate government agency (institution) and BAZNAS have roles as the regulator 
function and stakeholders, which have authority in reinforcement and monitoring of fintech-based zakat management. Therefore, based on this background description, this article offers concepts for innovation, reinforcement, strategy, and legality concerning the management of technology systems based on zakat. The purpose of this work is to be able to provide a diagram related to the phenomenon of managing information technology based on zakat and to provide a concept for the institution's function in supporting the reinforcement of zakat management.

\section{LITERATURE REVIEW}

\section{Financial Technology (Fintech) Systems}

Fintech is an innovation that uses technology within financial systems and financial services that create products, services, technology, and/or new models of business. It is able to affect the stability of the monetary system; the stability of financial systems; and/or the efficiency, fluency, security, and reliability of the payment systems (Peraturan Bank Indonesia, 2017; GSMA, 2017). The use of fintech is only the effective service devices, so there is no proven apriority that fintech will change the essence of intermediation in a financial system or the needed economic function. For a financial system in general, it is important to observe these functions as the continuous effort to reduce financial friction. This financial friction probably includes asymmetric information, an incomplete market, and negative externality, and can be closely related to an unharmonious incentive, the effect of a network, or behavioral distortion (FSB, 2017).

\section{Service Tools in Zakat Institutions}

In general, muzakki in Indonesia includes the upper middle class, who have a critical attitude and have a better ability to fulfil zakat payments. Therefore, zakat institutions need to improve muzakki satisfaction in ways such as facilitating zakat payments using an electronic approach. This is a new approach to zakat management, which is based on the behavior of muzakki, and is an important resource in zakat institutions. Understanding the behavior of the muzakki and maintaining good relations is the concept behind the need for optimizing the collection of zakat (Widarwati et al, 2017).

Optimizing the distribution of zakat funds is by providing the muzakki with facilities to distribute their own wealth to needy people (beneficiaries), while upholding transparency and accountability. That can be realized through an information system; the technology can accommodate the nature of trust in the process of distribution and zakat fund management. The use of information systems can streamline the power, streamline the time, and allow flexibility of the distribution range to be unlimited. The form of information system to be used is expected to be a platform that is simply a "web store" for donors and beneficiaries to interact with each other (Khoirun, 2016).

\section{Zakat Management based on Information Technology}

Conducting activities with technology media in the management of social funds is considered to be a production input for achieving optimal levels of efficiency and employment acceleration (Razimi et al., 2016). This can be achieved with a management information system. Sclot (2005) states that information systems can be used in real ways to control operations, 
strategies and planning, management control, and problem solving. The implementation of media technology by using applications, online, zakat payments, and zakat computer systems can improve performance and help zakat management to cover the wider society (Razimi et al., 2016), and support modernization and innovation (Makhtar and Ahmad, 2010).

There are many empirical studies related to the application of information media in the management of zakat. Bayu (2015) examines the level of efficiency of zakat management by using an information management system. Wahab et al. (2014) use technological variables with a data envelopment analysis method for a zakat institution. Eliyani and Handriani (2016) examine the application of a zakat acceptance system in zakat management.

\section{CONCEPT OF THE IDEA}

The rise in fintech features has increased the management of zakat in Indonesia. The development of a digital world of features has provided a convenient mechanism for the integration and management of zakat, and is able to involve the BAZNAS authority and the ministry of religion as the authority and regulator of zakat management, which has become crucial. The involvement of BAZNAS and the ministry of religion form the acceleration, regulation and supervising system for the management of zakat using technology features. It is considered to be important as the management of zakat, which is based on the principle of syariah, is able to support the effectiveness of management, innovation, velocity of performance growth, and accountability to build the trust of the community. The strategy of reinforcing zakat management through fintech was built based on improving the performance of amil through using digital technology (Internet and mobile applications) as the media of delivery of the products. The explanation for each part will be discussed as follows.

\section{Reinforcement System and Integrated Supervising}

The strategy of institution reinforcement is the effort to build organizations, systems, processes, rules and the governance of zakat related to the individual capability development, and building organizational and institutional capacity. It is considered to be important to create sturdy and strong ecosystems that are dynamic and sustainable. The strategy of reinforcing and supervising the management of zakat through fintech include the following basic principles, among others:

\section{Syariah Compliance}

The management system of zakat funds must be based on the principle of syariah; this means that the management of zakat is a religious command (Said et al., 2012). Fintech is a device used to easily access finances, and to run and support the management of zakat, which must be in accordance with obedience to syariah.

To create management that is appropriate to the principle of syariah, the authority institution needs to provide the requirements and standardization for the two basic structures: firstly, the technical structure in the form of akad decisions, administration costs, and the objective and calculation of zakat; and secondly, the structure of financial reporting that is based on the standard financial accounting of syariah. The next step is to provide the continuous function of syariah supervision of the fintech systems to strengthen the electability and existence of values that have been built. 


\section{Legal Compliance}

The principle of using fintech as the technology media in the management of zakat must be in accordance with the constitution or the rules of government. There are two aspects to the fintech-based management of zakat, namely the constitution concerning the management of zakat and information technology. Fulfillment of the legal principle is performed by the authority concerned giving permission and authorization to the media and fintech tools. The aspects of zakat management include the collection, distribution and utilization of zakat, and integrated reporting as contained in Government Regulation Number 14 of 2014 Regarding the Management of Zakat, Law Number 23 of 2011 Regarding the Management of Zakat and The Regulation of the Minister of Religion Number 52 of 2014 Regarding the Requirement and the Manner of Calculation of Zakat Mal and Zakat Fitrah as well as the Utilization of Zakat for the Productive Business. In addition, the information technology aspects are as contained in Law Number 11 of 2008 Regarding Information and Electronic Transactions.

\section{Accountability and Transparency}

Aspects that influence the community's perspective and commitment to the payment of zakat are accountability and transparency (Bayu, 2015). The fulfillment of the principle of accountability and transparency is realized through the presence of obligations for the amil zakat institutions (lembaga amil zakat [LAZ]), as well as fintech being the means to deliver the required financial reporting and operational accountability for the two stages of reporting. Firstly, the relevant authority, such as the ministry of religion or BAZNAS, must ensure that the intended reporting is in accordance with the standard syariah accounting and must submit the official report. This is intended so that the relevant authority is able to exercise control, at any time, over all transactions, the financial flow, governance, and the information system for zakat. The zakat utilization report is submitted periodically to the community, especially muzakki, both through information media or mailed through the postal system. The reporting to the community can be submitted only in the form of an official report and a basic financial report. This is intended to build the community's trust, good governance, and transparency of zakat management.

\section{Security}

The fulfillment of the principle of providing security and safety to the community is to be addressed to the donator, muzakki or to the mustahiq. The security factor is the effort to guarantee the flow and financial transactions, so as to avoid transaction risks, and to prevent criminal actions such as money laundering and manipulation efforts. With the guarantee of a safe and secure system, the community will not hesitate to use the fintech facilities in their funds transactions for zakat.

\section{The Big Concept}

In the effort to support the fulfillment of the principle of fintech reinforcement, there are four important concepts to be carried out, which are as follows:

\section{Integration}

Institutional integration between the LAZs and the relevant ministries - such as the ministry of religion, the ministry of social 
services, the ministry of information, and BAZNAS - is required in the effort to guarantee the sustainability and consistency of applying the rules, values, and principles to the fintech system that will be specified in the future. Each activity and organization that is directly involved in the improvement of zakat management must address mutual use and mutual strengthening, so it can cause greater results and impacts. In this case, the government and BAZNAS run the function to implement the regulation system, and must provide supervision and permissions, policy determination, research, support and protection of the fintech media and LAZs. Then the fintech media and LAZs perform the activities for zakat management in line with the specified requirements and regulations.

\section{Technology Development System}

A technology development system has two main focuses. Firstly, providing infrastructure development and information technology tools; this can be achieved through providing incentives, velocity of computerization system and provides easily networking. Secondly, the improving the skills of human resources, which, according to Silalahi (2000), is conducted through providing training, education, and coaching, especially in the field of information technology.

\section{Standardization}

Standardization is a method used to provide specific boundaries, and defines the objectives or characteristics of a process, and/or characteristics of running fintech systems. Standardization in the field of fintech includes standards for the infrastructure (both for hardware and software), and the skills and knowledge of the human resources, and refers to the management of the arrangement. This process must be followed and becomes a reference for each of the media services for fintech or LAZs. The standardization of zakat management using technology media includes standards for syariah, transaction costs, financial reports, transparency, management (for both the collection and distribution of zakat), and analysis. It is performed with the purpose of ensuring security, reducing risks, improving quality and services, and encouraging work effectiveness.

\section{Certification}

Certification is a determination provided by an authority or institution to a person or institution to indicate their ability to carry out an activity in accordance with the specified requirements. Certification has the purpose of making sure that an activity is performed in a legitimate way and reduces the possibility of authority misuse occurring. In this case, institution certification, especially for the information systems, is issued by the government through BAZNAS or through the forming of an independent third party. This certification institution checks there is a valid identity (such as performing digital certification under Electronic Certification Implementation in Law Number 11 of 2008 Regarding Information and Electronic Transactions); analyses the ability to manage zakat through LAZ and fintech; makes sure the transactions are sustainable, for both the collection and distribution of funds; and provides a rating for the marketplace or application in order to encourage the development of facilities and technology means, if needed. 


\section{Literacy and Education}

The implementation of literacy and education is intended to improve the understanding of the community regarding the payment of zakat and the fintech-based management of zakat. The process for literacy includes activities to emphasize the education aspect in the community (both for muzakki and mustahiq) for them to obtain information and knowledge regarding procedures and access, and choose a program. The concept of literacy includes education on information technology, finance and zakat management.

Figure 3. Structure of Reinforcement System and Integrated Supervising

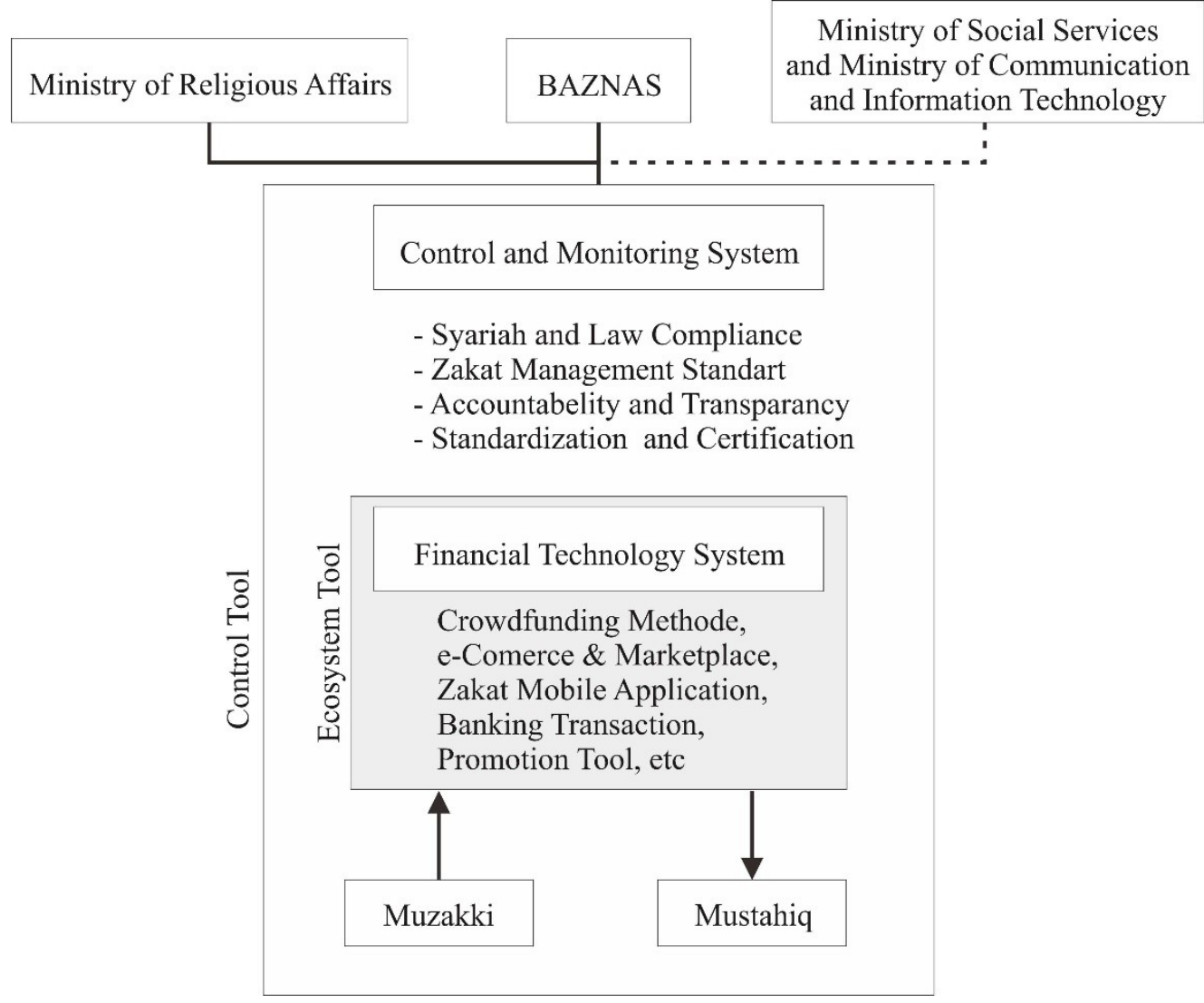

Purpose and Benefits

The process of developing and reinforcing zakat management through fintech has several purposes and benefits, as follows:

1. Improving the community's trust and growing social capital toward the information media of fintech as a tool and zakat management facility, and toward LAZs regarding the security and safety of zakat management.

2. Improving optimal services to provide convenience that meets the needs of the community, through improving both selfservice and full-service.

3. Encouraging progress and innovation in digital-technology-based zakat management by delivering easy access, and improving the quality of optimal products and services.

4. Improving competitiveness among of technology-based zakat management institutions, both among LAZs, technology media, and with institutions or other business fields. 
5. Maximizing the transparency and accountability of LAZs through technology media in order to achieve good corporate governance.

6. Improving literacy and education on zakat through authorities, zakat management institutions and fintech to the wider community.

7. Create an excellent ecosystem for zakat management, which is integrated and facilitates the mutual collaboration of human resources and business support.

Technical Concept for Applying Fintech to Zakat

As a broad outline, the concept of the idea of using technology media in the management of zakat is not only appropriate for the process of collecting zakat, but it is able to be applied to the process of distributing zakat. The process for implementing technology media can be explained as follows:

1. Implications of Fintech Model on the Collection of Zakat

There are many applications of the process for the collection of digital-based funds understood by the wider community. There are two main concepts in the application of fintech in the zakat management, namely the direct collection of zakat from the community through crowdfunding, and zakat payment through the information technology media such as e-commerce or the marketplace, zakat applications, online payments, and Islamic banking transactions. The explanation of both concepts is as follows.

A. In crowdfunding (especially the donationbased type), the creator (the person or institution collecting the funds) is able to make a campaign to accept donations.
The campaign contains detailed information about the distribution program (Belleflamme et al., 2014), and gives detailed information about that distribution program that will be created and performed. A proposed campaign for a program of zakat distribution must be in accordance with the interests, justice, and for the welfare of mustahiq. There are three steps to be implemented by the government function or BAZNAS in order to reinforce crowdfunding, which are the following:

1. Ensuring legality and providing supervision to two the main objects. Firstly, the actors related to the creator (in this case, LAZ), the government and BAZNAS determine the standards and validate the program to which donations will be given. Secondly, the information media fintech tools need to be examined regarding their legal standing, operational standards, and concept of akad in accordance with syariah.

2. Issuing certification and a security guarantee to the actors (giving a rating and assessment, if needed). This is perceived to be important in order to avoid the misuse of authority, increase security, provide operational standards, and to avoid criminal risks in the digital and financial fields.

3. Fulfilling their obligation to submit the accountability and integrated reporting, both to the relevant authority and the wider community. Mollick (2014) and Zheng et al. (2014) state that the provision of reporting and reward submissions to the community is considered to improve the performance of crowdfunding. 
B. Making transaction payments through ecommerce or marketplaces, zakat applications, online systems and Islamic banking tool transactions is not like crowdfunding; this concept only includes the tools and facilities for zakat payment transactions. In this case, the government function and BAZNAS, in an effort to reinforce technology-based zakat transactions, needs to provide operational standards and syariah standards within the facility, means and put infrastructure in place. Furthermore, certification can be obtained to secure the validity of the operations.

2. Implications of the Fintech Model on Zakat Distribution

The distribution of zakat funds through fintech is still not really experienced by the wider community, especially if compared with the concept of collecting zakat funds. According to Hamid et al. (2016) and Ahmad et al. (2015), the concept of fund distribution is addressed by the mustahiq against a background of a low-class community with respect to digital penetration, ownership of tools and infrastructure of lower specification information technology, which causes an information gap between mustahiq and muzakki emerge. The system of traditional distribution is more established and the limitation of adequately recourses. There are several research projects related to the concept of using technology in an effort to encourage efficiency in zakat distribution, but they only perform an external analysis and not do not investigate the technical application of real distribution; for example, the research of Lubis et al. (2011) concerning zakat distribution using a geographic information system, Hamid et al.'s (2016) study of the collection and distribution of zakat using customer relationship management (CRM), and Abral et al.'s (2016) research concerning zakat applications. To implement a fintech model for the distribution of zakat, the writer proposes the following steps and applicative concept:

\section{A. Proposal Submission}

The mustahiq or the community will suggest the distribution of zakat fund by submitting a proposal. Proposal submission is very important to determine the seriousness of the submission, drawing (description), criteria, budget, and data of mustahiq. A good proposal must include complete and accurate data, and photo of the conditions and activities to be carried out. This will allow the relevant LAZ to analyze and specify the steps of selection through the file proposed. The proposal can be submitted by filling in an application form provided by the fintech media or through uploading a file containing the proposal submission.

B. Analysis with Rating and Survey Using the Likert Scale Method.

The LAZ can propose several questions and check the completeness of the appropriate evidence. These questions include a character analysis and availability of capital, the capacity of mustahiq can be calculated using the Likert scale, and standard feasibility index for the mustahiq can be determined. If needed, a field survey will be performed for the LAZ to support the validity of the receiver.

C. Agreement and Recommendation for the Official or Community Figure

To strengthen the argument for the submission, it will be accompanied with the recommendation of the official or community figure for the surrounding 
area. The LAZ is able to provide the recommendation through information media and it can be uploaded by the mustahiq.

\section{Distribution}

In this step, the LAZ can distribute the zakat using two systems. Firstly, indirect distribution, for which the mustahiq or applicant must have a bank account, or the zakat funds can be distributed through the local official account. Secondly, through direct distribution, in which the LAZ distributes the zakat funds, as currency or in the form of goods, to the mustahiq directly without using a banking mediator.

\section{Impact and Challenge}

It is expected that the implementation of the concept of reinforcing and supervising zakat management through information media will have positive impacts on the various parties.

1. Impact for the Authority and Stakeholders

There is a positive impact for the authority and stakeholders of the policy, such as the government and BAZNAS, as follows:

a. It assures the sustainability, accountability, and transparency zakat management through information media and fintech.

b. It supports literacy and the provision of zakat for the wider community,

c. It increases the velocity of acceleration for improvements in the use of information technology in zakat management in accordance with BAZNAS's Renstra.
2. Impact for LAZs

The positive impacts of zakat management, for both LAZs and

BAZNAS itself, are as follows:

a. It reduces the gaps in the application of information technology to the management of zakat.

b. It encourage innovation, growth, and the development of existing institutions.

c. It explores more potential for zakat from the wider community.

d. It improves products for the management of zakat.

3. Impact for the Community

The positive impacts for the wider community, or for muzakki and mustahiq, are as follows:

a. It provides safe and secure transactions and payments.

b. It provides easy access to zakat services, both for muzakki and mustahiq.

4. Challenges

There are challenges that must be faced in the effort to apply fintech systems to the zakat management. These challenges need to be highlighted more to the institutions that manage zakat and the relevant authority:

a. There are gaps in resources, facilities and governance among zakat institutions. It needs to be addressed by providing education, improving competency, and giving incentives in order to enhance the standardization of the optimal management of zakat.

b. Internet penetration in Indonesia is still low; according to the APJII (2017) survey, Internet penetration has only reached 54.68 percent or only half of the total population. Therefore, much greater publication and promotion are needed. 
c. The awareness of the community about zakat payments is still low.

\section{CONCLUSION}

Fintech has penetrated the financial sector and played a major role in improving the quality and efficiency of financial services. In zakat management, innovation is required by applying fintech to zakat information systems. Although, recently, information technology has been applied to zakat management, there is no related regulation and standard rules. The existence of legal guidelines and guarantees from the government are expected to encourage the improvement of zakat management, increase innovation, and foster public trust. The fintech concept itself can create big data and transparency tools for zakat management ecosystems to provide more effective and efficient management.

The process of strengthening and supervising zakat management should be through using strategic steps that are structured to realize the development acceleration of zakat management. These processes include aspects of legal compliance, syariah compliance, accountability, and a security structure. This can be realized through institutional integrity, technology development systems, standardization, certification, and education.

\section{REFERENCES}

Abdelkader, O. A. (2017). Significant concerns influence online pro bono volunteering of faculty members. Computers in Human Behavior, 73, 547-553.

Abral, E., Anwar, \& Harianto, S. (2016). Design of accounting information system for zakat in Amil Zakat
Institution in Lhokseumawe City. IOSR Journal of Computer Engineering, 18(6), 25-37.

Ahmad, R. A., Othman, A. M., \& Salleh, M. S. (2015). Assessing the satisfaction level of zakat recipients towards zakat management. Procedia Economics and Finance, 31, 140-151.

Badan Amil Zakat Nasional. (2016). Rencana strategis (Renstra) BAZNAS 2016-2020. Accessed from http://pid.baznas.go.id/rencanastrategis-2016-2020/

Bayu, M. R. (2015). Penerapan sistem informasi manajemen pada Badan Amil Zakat Nasional (BAZNAS) dalam peningkatan akuntabilitas dan mutu pengelolaan zakat, infaq dan sedekah (Thesis).

Belleflamme, P., Lambert, T., \& Schwienbacher, A. (2014). Crowdfunding: Tapping the right crowd. Journal of Business Venturing, 29(5), 585-609.

Eliyani \& Handriani, I. (2016). Zakat acceptance system on national level of zakat management organization in Indonesia. Journal Islamic Finance Studies, 2(2), 67-74.

FSB. (2017). Financial stability implications from FinTech. Accessed from http://www.fsb.org/wpcontent/uploads/R270617.pdf

GSMA. (2017). State of the industry report on mobile money: Decade edition 2006-2016. Accessed from http://www.gsma.com/mobilefordevel opment/wp-content/uploads/2017/03/ GSMA_State-of-the-Industry-Reporton-Mobile-Money 2016.pdf

Hadad, M. D. (2017) Financial technology di Indonesia [Financial technology of Indonesia]. Accessed from http://www.ibs.ac.id/img/doc/MDH\%2 $\underline{0-}$ 
\%20FinTech $\% 20$ IBS $\% 20 J u n e \% 20201$ 7.pdf

Imansyah. (2016, November) Urgensi Perlunya Pengaturan Financial Technology. Accessed from http://mediaindonesia.com/read/detail/ 78124-urgensi-perlunya-pengaturanfinancial-technology-1

Jutla, S. \& Sundararajan, N. (2016). The FINTECH book: The financial Technology handbook for investors, entrepreneurs and visionaries (h. 5657). Accessed from https://www.wiley.com

Khoirun, N. (2016). Perancangan sistem informasi penyaluran dana zakat, infak \& sedekah berbasis aplikasi web menggunakan codeigniter web framework (Essay). Muhammadiyah University of Surakarta, Indonesia.

Lubis, M., Yaaqob, N. I., Omar, Y., \& Dahlan, A. R. (2011). Enhancement of zakat distribution management system: Case study in Malaysia. International Management Conference 2011 Proceedings, 1-10. Accessed from http://irep.iium.edu.my

Makhtar, A. S. \& Ahmad, S. (2010). Transformasi pengurusan zakat di Malaysia. Paper presented at the 4th ISDEV International Islamic Development Conference (IDMAC 2010) organized by the Centre for Islamic Development Management Studies (ISDEV), University of Science, Malaysia.

Mollick, E. (2014). The dynamics of crowdfunding: An exploratory study. Journal of Business Venturing, 29 (1), $1-16$.

Said, J. Ghani, E. K., Zawawi, S. N., \& Yusof, S. N. (2012). Composite performance for zakat organizations. British Journal of Economics, Finance and Management Sciences, 4 (1), 5059. $\begin{array}{rrr}\text { Peraturan } & \text { Bank } & \text { Indonesia } \\ \text { No.19/12/PBI/2017 } & \text { tentang }\end{array}$ Penyelenggaraan Teknologi Finansial, Indonesia.

Ramizi, M. S., Romle, A. R., \& Erdris, M. F. (2016). Zakat management in Malaysia: A review. AmericanEurasian Journal of Scientific Research, 11(6), 453-457.

Silalahi, B. (2000). Manajemen sumberdaya manusia, sekolah tinggi ilmu manajemen. Jakarta, Indonesia: LPMI.

Wahab, N. A., Rahim, A., \& Rahman, A. (2014). Efficiency of zakat institutions and its determinants. Paper presented at 8th International Conference on Islamic Economics and Finance held by Islamic Research and Training Institute (IRTI), Doha, 19 December.

Wibisono, Y. (2016). Potensi zakat nasional: Peluang dan tantangan pengelolaan. Accessed from https://puskasbaznas.com/images/ppt/ Panel-1 Yusuf-WIbisono.pdf

Zhang, J. \& Liu, P. (2012). Rational herding in microloan markets. Management Science, 58(5), 892-912.

M. Aulia Rachman

Diponegoro University

maulrachman@gmail.com

Annisa Nur Salam

Diponegoro University

annisa.nursalam95@gmail.com 